\title{
Razlike u podložnosti vršnjačkom pritisku studenata u različitim mjestima studiranja
}

\author{
Mirjana Radetić-Paić \\ Sveučilište Jurja Dobrile u Puli, Fakultet za odgojne i obrazovne znanosti, \\ Hrvatska \\ e-mail:mradeticpaic@hotmail.com
}

\author{
Jasna Kudek Mirošević \\ Sveučilište u Zagrebu, Učiteljski fakultet, Hrvatska \\ e-mail: jasna.kudek@ufzg.hr
}

\section{Sandra Kadum}

Sveučilište Jurja Dobrile u Puli, Fakultet za odgojne i obrazovne znanosti, Hrvatska

e-mail:skadum@unipu.hr

SAŽETAK Ključnu ulogu u razdoblju adolescencije zauzimaju vršnjački odnosi. Posredno ili neposredno, ti odnosi imaju za posljedicu potrebu za činjenjem onoga što zahtijevaju vršnjaci, a što je vidljivo po odlukama koje adolescenti donose, kao i po načinu na koji se ponašaju. Cilj ovoga rada je utvrditi jesu li i u kojem obimu studenti podložni vršnjačkom pritisku i, ako jesu, koja su to specifična obilježja razlika u podložnosti tom pritisku između studenata Fakulteta za odgojne i obrazovne znanosti Sveučilišta Jurja Dobrile u Puli i Učiteljskog fakulteta Sveučilišta u Zagrebu, Odsjeka u Petrinji $(\mathrm{N}=440)$. Rezultati pokazuju da su studenti svoju podložnost vršnjačkom pritisku procjenjivali vrlo malom. Zaključuje se da obilježja okruženja nisu u većoj mjeri djelovala na podložnost vršnjačkom pritisku studenata koji su u navedene gradove došli studirati u dobi već kasne adolescencije, koju obilježava manja podložnost vršnjačkom pritisku. Kod studenata promatranih fakulteta koji su ponekad bili podložni vršnjačkom pritisku postoje razlike u specifičnim obilježjima te podložnosti, no one su također male. Temeljem dobivenih razlika zaključuje se da je kod studenata grada Petrinje veća socijalna kontrola, pa su tako i češća konformistička ponašanja koja studenti usvajaju kako bi se uklopili. Doprinos rada očituje se u uvidu o obimu vršnjačkog pritiska kod studenata, ali i sagledavanju razlika u specifičnim obilježjima podložnosti vršnjačkom pritisku studenata koji su mu podložni s dvaju srodnih fakulteta. Također, činjenica da ne postoje ili su izrazito rijetka istraživanja ove vrste o povezanosti vršnjačkog pritiska s različitim okruženjima dodatni je doprinos ovog rada.

Ključne riječi: adolescenti, okolina, otpornost, utjecaji, vršnjaci. 


\section{Uvod}

Utjecaj okoline na pojedinca proces je koji počinje od samog rođenja. Okolina utječe na formiranje ponašanja, socijalizaciju, stavove i mišljenja. U različitim razdobljima života različite će osobe i skupine imati utjecaja na mladu osobu. Najprije će to biti roditelji, a u doba adolescencije to će biti vršnjaci. Vršnjački odnosi zauzimaju ključnu ulogu u razdoblju adolescencije, što često ima za posljedicu potrebu za činjenjem onoga što zahtijevaju vršnjaci, a što je vidljivo po odlukama koje adolescenti donose, kao i po načinu na koji se ponašaju (Lerner i Steinberg, 2004.; Lebedina-Manzoni, Lotar i Ricijaš, 2008.; Allen i sur., 2012.). Naime, mlada je osoba u svom razvojnom razdoblju podložna različitim utjecajima. To mogu biti roditelji, vršnjaci, prijatelji, mediji, druge socijalne okoline, no i brojni oblici moguće manipulacije (Zloković i Vrcelj, 2010.), što može postati problem.

Vršnjački pritisak, u negativnom kontekstu, može se vršiti na različite načine, čemu pogoduju obilježja odrastanja adolescenata, koji su često nesigurni i potreban im je osjećaj prihvaćanja i pripadnosti. Pritisak vršnjačke skupine na pojedinca veći je ukoliko pojedinac ima manje samopoštovanje i obrnuto (Kaplan, 2004.; Prinstein, 2007.).

Autorica Maleš (1995.) navodi da skupine razvijaju svoje vlastite oblike ponašanja i određuju norme koje obavezuju sve članove skupine, a njihovim poštivanjem adolescenti se osjećaju jačima, kompenziraju svoju nesigurnost i još neizgrađenu ličnost. Pri tome se određeni broj adolescenata, kako ih vršnjačka skupina ne bi izopćila, nekritički stapa sa skupinom, čak i ako se s njihovim normama i stilovima ponašanja ne slaže. U pozadini takvog ponašanja pojedinaca obično se krije nedostatak samopouzdanja i osjećaj manje vrijednosti (Đuranović, 2014.).

U skladu sa samoprocjenama o manjoj otpornosti na vršnjačke utjecaje među adolescentima za razliku od odraslih (Steinberg i Monahan, 2007.), podaci ukazuju na ulogu vršnjačkih utjecaja kao primarnog kontekstualnog čimbenika koji pridonosi povećanoj sklonosti adolescenata da donose rizične odluke. Primjerice, mnogobrojni autori u svojim istraživanjima, kada se radi o kaznenim djelima (Zimring, 1998.; LeBlanc i Morizot, 2000.; Chassin i sur., 2004.; Simons-Morton, Lerner i Singer, 2005.; Miner i Munns, 2005.), dolaze do podataka da adolescenti obično počinju delinkventne radnje u vršnjačkim skupinama, za razliku od odraslih. Nadalje, jedan od najsnažnijih prediktora delinkventnog ponašanja u adolescenciji povezanost je $s$ delinkventnim vršnjacima, što se u različitim razmjerima pripisuje vršnjačkoj socijalizaciji (Dishion, Bullock i Granic, 2002.; Nsofor, 2013.) te izboru prijatelja, pri čemu adolescenti koji preuzimaju rizik prirodno gravitiraju jedan prema drugome (Bauman i Ennett, 1996.; Dishion, 2000.; Henslin, 2008.; Carlson, 2012.).

Kako bismo određene postupke skupine vršnjaka mogli povezati $s$ vršnjačkim pritiskom, potrebno je steći uvid u određena obilježja koja ga opisuju. Tako Brown, Claser 
i Eichler (1986., prema Lebedina-Manzoni i sur., 2008.) navode četiri osnovna obilježja vršnjačkog pritiska:

- višedimenzionalnost - pojedinac u raznim područjima svog života percipira vršnjački pritisak

- višesmjernost - vršnjačka skupina traži od pojedinca da nešto napravi ili ne napravi

- pritisak skupine može postojati i prema negativnom i prema pozitivnom ponašanju

- mijenja se kroz pojedina razdoblja života.

U tom kontekstu McIntosh, MacDonald i McKeganey (2003.) navode da, primjerice, radoznalost, vanjski utjecaji i želja za prihvaćanjem djeluju kao dio složene dinamike. Također, autori navode potrebu distinkcije pojmova vršnjačkog pritiska i vršnjačkog utjecaja s obzirom na to da osim izravne prisile vršnjaci utječu i na ponašanje pojedinaca na druge načine. Naime, odabir prijatelja istomišljenika i proces socijalizacije kojim pojedinci internaliziraju stavove i vrijednosti skupine značajni su u razumijevanju mehanizama koji dovode do manifestacije određenog ponašanja. Međutim, temeljem mnogobrojnih istraživanja (Lashbrook, 2000.; Kiran-Esen, 2003.; Sim i Koh, 2003.; Brown, 2004.) zaključuje se da je pojam vršnjačkog pritiska uži konstrukt u odnosu na pojam vršnjačkog utjecaja, a odnosi se na očekivanja vršnjaka da se pojedinac ponaša na određeni način bez obzira na svoje želje (Lebedina-Manzoni i Ricijaš, 2013.).

Epstein i Pacini (1999., prema Wolff, 2012.) navode da svatko koristi i deliberativne i intuitivne stilove donošenja odluka, ali postoje značajne individualne razlike u količini i kvaliteti njihove uporabe. Naime, ponašanje je složeno jer na njega utječu brojne okolinske varijable i različiti individualni čimbenici, iskustva i događaji. Upravo takve individualne razlike kao što su sposobnosti/vještine, osobnost, percepcije i iskustva utječu na ponašanje. Primjerice, smatra se da su temperamentni aspekti, kao što je samoregulacija, važni za adolescente da donose dobre odluke (Byrnes, 2002.; Steinberg, 2007.). Iako neurobiološki model karakterizira samoregulaciju kao razvojnu varijablu koja se općenito definira kao kontrolni impulsi, postoje i individualne razlike u razinama samoregulacije među adolescentima iste dobi (Raffaelli i Crockett, 2003.).

Kada se radi o podložnosti vršnjačkom pritisku vezanoj za određenu dob, Steinberg i Monahan (2007.) navode da su ranija istraživanja opisivala razvoj osjetljivosti na vršnjački pritisak u adolescenciji kao obrnutu krivulju (u obliku slova U), koja raste tijekom rane adolescencije, dostiže vrhunac oko četrnaeste godine života i nakon toga opada. Isti su autori (Steinberg i Monahan, 2007.) u svom longitudinalnom i dva krossekcijska istraživanja, na više od tri tisuće i šest stotina sudionika u dobi od deset do trideset godina života, procjenjivali starosne razlike i razvojne promjene u otpornosti prema vršnjačkom utjecaju pomoću instrumenta koji razdvaja podložnost vršnjačkom pritisku od spremnosti za sudjelovanje $u$ antisocijalnim aktivnostima. Rezultati su po- 
kazali da se u svim demografskim skupinama otpornost na vršnjačke utjecaje linearno povećava između četrnaeste i osamnaeste godine, dok je tzv. srednja adolescencija posebno značajno razdoblje za razvoj sposobnosti da se zauzme za ono što netko vjeruje i da se odupre pritiscima svojih vršnjaka da učini drugačije. Pri tome treba uzeti u obzir da studenti na studij dolaze u dobi kasne adolescencije te se značaj pridaje njihovoj prilagodbi na (novu) sredinu, a treba uzeti u obzir i društvene, kulturalne i ostale razlike u uvjetima i načinu studiranja (Živčić-Bećirević i sur., 2007.). Prilagodba se može procijeniti, između ostalog, kroz uključenost u različite aktivnosti na fakultetu, razvoj, održavanje i kvalitetu odnosa s kolegama, potrebu korištenja dodatnih izvora podrške za vrijeme eventualnih teškoća i sl. (Taylor, Peplau i Sears, 2000.; Lee, Keough i Sexton, 2002.). Kada se radi o kvaliteti emocionalne prilagodbe, važna je i dostupnost dodatnih izvora podrške (Živčić-Bećirević i sur., 2007.), kao npr. Studentsko savjetovalište koje ima Sveučilište Jurja Dobrile u Puli. Navedene su pretpostavke važne jer prema programu i strategiji razvoja obaju gradova (Program ukupnog razvoja Petrinje 2014. - 2020., Lokalni program za mlade Grada Pule 2018. - 2020., Strategija razvoja Grada Pule, 2010.), u visokom obrazovanju potiču što veću samostalnost svojih fakulteta u cilju unapređenja kapaciteta te kvalitete u sustavu obrazovanja općenito, čime potiču opću razinu svijesti o potrebi ulaganja u odgoj i obrazovanje u Republici Hrvatskoj. Provedbom tih mjera gradovi pokušavaju stvoriti preduvjete za dostizanje standarda nacionalnog i europskog obrazovnog sustava.

Analiziranjem gradova Pule i Petrinje vidljivo je da su ti gradovi različitih društvenih, kulturnih i gospodarskih obilježja, između ostalog i s obzirom na činjenicu da je grad Petrinja bio izravno izložen razaranjima tijekom Domovinskog rata, čije se posljedice na stanovništvo osjećaju još i danas, posebice na psihološkom planu, najčešće u vidu posttraumatskih teškoća. Međutim, i Istra je tijekom 20. stoljeća prolazila kroz razdoblje demografske tranzicije, kao i grad Petrinja u Sisačko-moslavačkoj županiji iza Domovinskog rata, no ne na isti način. Također, u Puli je depopulacija stanovništva nešto manja i ne očituje se velikim emigracijama budući da je Pula grad Istarske županije, koja je među najbogatijim županijama u Hrvatskoj. U oba grada djeluju fakulteti slični po broju upisnih kvota, no Petrinja je dislocirana u odnosu na veće sveučilište, dok se u Puli nalazi sveučilište sa svim pripadajućim sadržajima koji grad čini sveučilišnim, dakle s boljim uvjetima studiranja. Sve navedeno utječe na ozračje među stanovništvom, pa se pretpostavlja i među studentima. Općenito gledajući, razlike između navedenih gradova možemo promatrati kroz razlike u načinu i obilježjima života u smislu da Petrinja ima više ruralna obilježja, a Pula urbana, a procjenjuje se i da je životni standard različit. U skladu s tim, različita okruženja obilježavaju različiti stavovi, vrijednosti i razmišljanja, temeljem kojih se u njima stanovnici i ponašaju. Također, u različitim su okruženjima i različiti stupnjevi društvenih, ali i psiholoških odnosa i te su razlike posljedično vidljive i u različitim rizičnim ponašanjima (Knecht i sur., 2010; Widman i sur., 2016.), posebno mladih na čije ponašanje vršnjačke skupine u toj dobi mogu imati utjecaj. U tom kontekstu može se pretpostaviti da je u 
Petrinji veća socijalna kontrola, pa tako i konformistička ponašanja koja će studenti usvojiti kako bi se što bolje uklopili, ali i izbjegavali osobe koje ne pripadaju vršnjačkoj skupini i obrnuto.

\section{Cilj i hipoteza}

Cilj ovoga rada utvrditi je jesu li i u kojem obimu studenti podložni vršnjačkom pritisku i, ukoliko jesu, koja su to specifična obilježja razlika u podložnosti tom pritisku između studenata Fakulteta za odgojne i obrazovne znanosti Sveučilišta Jurja Dobrile u Puli i Učiteljskog fakulteta Sveučilišta u Zagrebu, Odsjeka u Petrinji.

U skladu s navedenim ciljem postavljene su hipoteze H1: studenti su podložni vršnjačkom pritisku i H2: postoje razlike u specifičnim obilježjima podložnosti vršnjačkom pritisku između studenata Fakulteta za odgojne i obrazovne znanosti Sveučilišta Jurja Dobrile u Puli i Učiteljskog fakulteta Sveučilišta u Zagrebu, Odsjeka u Petrinji.

Smjer očekivanih razlika među studentima iz promatranih gradova odnosi se na razlike u pretežito ruralnim, odnosno pretežito urbanim obilježjima života te životnom standardu u najširem smislu, koji utječu na vrijednosti, interese i razmišljanja stanovništva, posebice mladih. Naime, iako se u današnje vrijeme gube razlike između ruralnog i urbanog u smislu da svijet postaje „globalno selo“ (Alić, 2009), petrinjsko područje ima još uvijek obilježja ruralne sredine nižeg standarda za razliku od Pule, posebice nakon Domovinskog rata, što se očituje, pored različitih društvenih odnosa, i u psihološkim odnosima i ponašanju stanovništva.

\section{Metode}

\subsection{Uzorak sudionika}

Prigodni uzorak sudionika čini 440 studenata, od čega 234 studenata Fakulteta za odgojne i obrazovne znanosti Sveučilišta Jurja Dobrile u Puli (53,2\%) i 206 studenata Učiteljskog fakulteta Sveučilišta u Zagrebu, Odsjeka u Petrinji (46,8\%). U oba fakulteta u istraživanje su bili uključeni studenti Učiteljskog studija te studenti redovnog i studenti izvanrednog studija Ranog i predškolskog odgoja i obrazovanja. S obzirom na spol, u istraživanju je sudjelovalo $425(96,6 \%)$ osoba ženskog spola i $15(3,4 \%)$ osoba muškog spola, dakle više sudionica nego sudionika. Tablica 1 prikazuje uzorak sudionika prema godini studija u akademskoj godini 2018./2019. 
Tablica 1.

Godina studija sudionika $(\mathrm{N}=440)$

\begin{tabular}{|c|c|c|c|c|c|c|}
\hline $\begin{array}{c}\text { Godina } \\
\text { studija }\end{array}$ & $\begin{array}{c}\text { Ukupan broj } \\
\text { studenata }\end{array}$ & Pula & Petrinja & $\begin{array}{c}\text { Ukupni } \\
\text { postotak } \\
\text { studenata } \\
(\%)\end{array}$ & $\begin{array}{c}\text { Pula } \\
(\%)\end{array}$ & $\begin{array}{c}\text { Petrinja } \\
(\%)\end{array}$ \\
\hline 1. & 75 & 73 & 2 & 17,1 & 31,2 & 1 \\
\hline 2. & 170 & 78 & 92 & 38,6 & 33,3 & 44,7 \\
\hline 3. & 100 & 51 & 49 & 22,7 & 21,7 & 23,8 \\
\hline 4. & 51 & 16 & 35 & 11,6 & 6,9 & 17 \\
\hline 5. & 44 & 16 & 28 & 10,0 & 6,9 & 13,5 \\
\hline Ukupno & 440 & 234 & 206 & 100 & 100 & 100 \\
\hline
\end{tabular}

Udio studenata koji su upisali studij u mjestu prebivališta, odnosno odrastali u promatranim gradovima za Pulu iznosi 44 (19\%), a za Petrinju 12 (6\%).

Sudionika istraživanja najviše je u dobi od 18. do 22. godine života - 325 (74\%), nešto manje je u dobi od 22. do 25 . godina života - 100 (23\%), a starijih od 25 . godina života je 15 (3\%).

\subsection{Mjerni instrument, način prikupljanja i metode obrade podataka}

$\mathrm{U}$ istraživanju je korišten mjerni instrument Upitnik vršnjačkog pritiska (LebedinaManzoni i sur., 2008.). ${ }^{1}$ Upitnik su konstruirali studenti treće godine studija Socijalne pedagogije Edukacijsko-rehabilitacijskog fakulteta Sveučilišta u Zagrebu, a prema Upitniku vršnjačkog utjecaja kod adolescenata konstruiranom za populaciju srednjoškolaca, koji su konstruirali studenti studija Socijalne pedagogije Edukacijsko-rehabilitacijskog fakulteta Sveučilišta u Zagrebu te adaptirali Lebedina-Manzoni i Ricijaš (2007., prema Lebedina-Manzoni i sur., 2008.).

Upitnik se sastoji od 25 čestica/varijabli na peterostupanjskoj skali Likertovog tipa (1 = nikad, 2 = rijetko, 3 = ponekad, 4 = često, 5 = uvijek). Više vrijednosti postignute na skali predstavljaju i višu samoprocjenu podložnosti vršnjačkom pritisku. U podacima nije bilo nedostajućih vrijednosti. Unutarnja konzistencija skale izražena Cronbachovim alfa koeficijentom je ,89.

Istraživanje je provedeno akademske 2018./2019. godine među studentima Fakulteta za odgojne i obrazovne znanosti Sveučilišta Jurja Dobrile u Puli te Učiteljskog fakulteta Sveučilišta u Zagrebu, Odsjeka u Petrinji. Podaci su prikupljeni tijekom nastave,

1 Za korištenje upitnika dobiven je pismeni pristanak autora. 
tj. ispitani su oni studenti koji su prilikom ispitivanja prisustvovali nastavi. Prilikom ispitivanja poštovani su etički standardi ${ }^{2}$, tj. sudionici su upoznati s ciljem i svrhom provođenja istraživanja, dane su im upute o načinu ispunjavanja upitnika, zajamčila im se anonimnost, mogućnost odustajanja bez posljedica te im se objasnilo da će se podaci koristiti isključivo u znanstvene svrhe.

U obradi podataka, uz izračunavanje osnovnih statističkih vrijednosti, korištena je diskriminacijska analiza radi utvrđivanja diskriminacijskih varijabli odnosno latentnih dimenzija po kojima se razlikuju promatrane skupine i univarijatna analiza varijance radi uvida u postojanje eventualnih razlika aritmetičkih sredina između skupina na manifestnim varijablama, a koje su sastavni dio licenciranog SPSS programa 24.0 Standard Campus Edition (SPSS ID: 729357 20.05.2016.).

\section{Rezultati i rasprava}

Iz tablice 2 vidljivo je da su prosječne razine podložnosti vršnjačkom pritisku studenata obaju promatranih fakulteta niske i kreću se najvećim dijelom u kategorijama „nikad“ i ,rijetko“. Studenti ukupnog uzorka procjenjivali su višom vlastitu podložnost vršnjačkom pritisku za čestice/varijable (V14), (V18), (V3) i (V1), no ne višom nego „ponekad“. To je u skladu s tumačenjima Monahan i sur. (2009.), koji navode da je adolescentima u dobi od šesnaeste do dvadesete godine života važna samo socijalizacija, a nakon dvadesete godine utjecaj vršnjaka na asocijalno ponašanje nestaje jer pojedinci postaju sve otporniji na utjecaj vršnjaka te proces otpora asocijalnom ponašanju može biti povezan s normativnim promjenama u vršnjačkim odnosima koje se javljaju kako pojedinci sazrijevaju socijalno i emocionalno.

Tablica 2.

Mjere centralne tendencije i raspršenja

\begin{tabular}{|l|c|c|c|c|}
\hline \multicolumn{1}{|c|}{ Varijable } & Min. & Max. & $\begin{array}{c}\text { Aritmetička } \\
\text { sredina }\end{array}$ & $\begin{array}{c}\text { Std. } \\
\text { devijacija }\end{array}$ \\
\hline $\begin{array}{l}\text { V1 Važno mi je biti sličan društvu u kojem se krećem da bih } \\
\text { se dobro osjećao/la. }\end{array}$ & 1 & 5 & 2,7 & 1,03 \\
\hline $\begin{array}{l}\text { V2 Ponašam se na način koji mi ne odgovara da bih se } \\
\text { uklopio/la u grupu. }\end{array}$ & 1 & 4 & 1,5 &, 69 \\
\hline V3 Važno mi je što drugi misle o meni. & 1 & 5 & 2,8 &, 82 \\
\hline V4 Svoj izgled uspoređujem s drugima. & 1 & 5 & 2,4 &, 93 \\
\hline
\end{tabular}

2 Istraživanje je odobreno odlukom Povjerenstva za procjenu etičnosti istraživanja Fakulteta za odgojne i obrazovne znanosti Sveučilišta Jurja Dobrile u Puli. 


\begin{tabular}{|c|c|c|c|c|}
\hline Varijable & Min. & Max. & $\begin{array}{l}\text { Aritmetička } \\
\text { sredina }\end{array}$ & $\begin{array}{c}\text { Std. } \\
\text { devijacija }\end{array}$ \\
\hline $\begin{array}{l}\text { V5 Moje razmišljanje i stavovi temelje se na razmišljanju i } \\
\text { stavovima mog društva. }\end{array}$ & 1 & 5 & 1,8 & ,84 \\
\hline $\begin{array}{l}\text { V6 Važnije mi je raditi ono što vršnjaci očekuju od mene } \\
\text { nego udovoljiti vlastitim željama. }\end{array}$ & 1 & 4 & 1,4 & ,63 \\
\hline $\begin{array}{l}\text { V7 Bojim se da ću ispasti glup/a pred društvom zbog svojeg } \\
\text { mišljenja ili ponašanja. }\end{array}$ & 1 & 5 & 1,8 & 90 \\
\hline $\begin{array}{l}\text { V8 Odustat ću od svojeg mišljenja/vrijednosti/stavova ako } \\
\text { se razlikuju od onih u mom društvu. }\end{array}$ & 1 & 4 & 1,4 & ,63 \\
\hline $\begin{array}{l}\text { V9 Važno mi je biti popularan/na u društvu u kojem se } \\
\text { krećem. }\end{array}$ & 1 & 5 & 1,6 & ,90 \\
\hline $\begin{array}{l}\text { V10 Kad sam u svom društvu, izbjegavam osobe koje mu ne } \\
\text { pripadaju. }\end{array}$ & 1 & 5 & 1,8 & 1,00 \\
\hline $\begin{array}{l}\text { V11 Moje ponašanje temelji se na ponašanju osoba iz mog } \\
\text { društva. }\end{array}$ & 1 & 5 & 1,8 & 90 \\
\hline $\begin{array}{l}\text { V12 Kad se družim s ljudima koji uzimaju drogu, dođem u } \\
\text { napast da je i ja probam. }\end{array}$ & 1 & 5 & 1,2 & ,62 \\
\hline $\begin{array}{l}\text { V13 Uzimam drogu jer želim doživjeti "super“ osjećaj koji je } \\
\text { iskusio ostatak mog društva. }\end{array}$ & 1 & 5 & 1,1 &, 51 \\
\hline V14 Važno mi je što moje društvo misli o meni. & 1 & 5 & 3,1 & 1,05 \\
\hline $\begin{array}{l}\text { V15 Kada se nađem u situaciji da svi konzumiraju alkohol, a } \\
\text { ja ne, imam osjećaj da se ne mogu uklopiti/zabaviti/opustiti. }\end{array}$ & 1 & 5 & 1,7 & ,94 \\
\hline $\begin{array}{l}\text { V16 Važno mi je imati iste stavove, vrijednosti i mišljenje } \\
\text { kao i moje društvo da bih se dobro osjećao/la u njemu. }\end{array}$ & 1 & 5 & 1,9 & 90 \\
\hline $\begin{array}{l}\text { V17 Treba mi pohvala moje "ekipe“ da bih imao/la dobro } \\
\text { mišljenje o sebi. }\end{array}$ & 1 & 5 & 1,9 & 90 \\
\hline $\begin{array}{l}\text { V18 Mjesto izlaska biram u skladu s odabirom i ukusom mog } \\
\text { društva. }\end{array}$ & 1 & 4 & 3 & 1,12 \\
\hline $\begin{array}{l}\text { V19 Moji prijatelji i ja teško prihvaćamo osobe koje se } \\
\text { drukčije odijevaju ili slušaju drukčiju vrstu glazbe od nas. }\end{array}$ & 1 & 5 & 1,7 & 96, \\
\hline $\begin{array}{l}\text { V20 Upustit ću se u rizična ponašanja ako to moje društvo } \\
\text { traži od mene. }\end{array}$ & 1 & 5 & 1,3 & ,61 \\
\hline V21 Kladim se / kockam zato jer to rade i moji prijatelji. & 1 & 3 & 1 & ,26 \\
\hline $\begin{array}{l}\text { V22 Sudjelovao/la bih na nekom studentskom prosvjedu iako } \\
\text { osobno ne podržavam njihove ideje. }\end{array}$ & 1 & 5 & 1,3 &, 56 \\
\hline $\begin{array}{l}\text { V23 Ostajem vani dulje nego bih htio/htjela jer moji } \\
\text { prijatelji to očekuju od mene. }\end{array}$ & 1 & 5 & 1,6 & ,79 \\
\hline $\begin{array}{l}\text { V24 Osjećam se manje vrijednim/om jer imam manje } \\
\text { seksualnog iskustva od ostatka svog društva. }\end{array}$ & 1 & 5 & 1,2 &, 50 \\
\hline V25 Moje društvo ima utjecaj na moje seksualno ponašanje. & 1 & 4 & 1,1 & ,46 \\
\hline Ukupno & 1 & 4,7 & 1,8 & ,78 \\
\hline
\end{tabular}


Razlike u samoprocjenjivanju pojedinih obilježja podložnosti vršnjačkom pritisku $s$ obzirom na mjesto studiranja kod studenata koji jesu podložni vršnjačkom pritisku ispitane su temeljem diskriminacijske analize kako bi se stekao uvid u latentne dimenzije tih razlika. Prethodno testiranje distribucije podataka Kolmogorov-Smirnov testom ukazuje na normalnu distribuciju podataka. Također, rezultati testiranja multikolineranosti u cilju kontrole njene značajnosti pokazuju da multikolineranost nije značajna. tj. VIF-ovi svih varijabli manji su od pet. Time je ispunjena pretpostavka da su regresijske varijable međusobno nezavisne.

Diskriminacijska analiza učinjena je na skupu čestica kojima se opisuju pojedina obilježja podložnosti vršnjačkom pritisku. $S$ obzirom na to da je provedena diskriminacijska analiza na samo dvije skupine sudionika - studenata Fakulteta za odgojne i obrazovne znanosti Sveučilišta Jurja Dobrile u Puli i Učiteljskog fakulteta Sveučilišta u Zagrebu, Odsjeka u Petrinji, dobivena je jedna diskriminacijska funkcija koja je statistički značajna na razini $\mathrm{p}=, 01$ i diskriminira promatrane skupine sudionika. Kanonička korelacija iznosi ,322 i pokazuje relativno dobru diskriminacijsku moć te funkcije u praktičnom smislu.

Tablica 3.

Standardizirani kanonički diskriminacijski koeficijenti funkcije (C) i struktura matrice (S)

\begin{tabular}{|l|c|c|}
\hline \multicolumn{1}{|c|}{ Varijable } & C & S \\
\hline V1 Važno mi je biti sličan društvu u kojem se krećem da bih se dobro osjećao/la. &,- 206 &,- 075 \\
\hline V2 Ponašam se na način koji mi ne odgovara da bih se uklopio/la u grupu. &, 409 &, $305^{*}$ \\
\hline V3 Važno mi je što drugi misle o meni. &,- 388 &,$- 310^{*}$ \\
\hline V4 Svoj izgled uspoređujem s drugima. &, 221 &, 104 \\
\hline V5 Moje razmišljanje i stavovi temelje se na razmišljanju i stavovima mog društva. &, 015 &, 053 \\
\hline $\begin{array}{l}\text { V6 Važnije mi je raditi ono što vršnjaci očekuju od mene nego udovoljiti vlastitim } \\
\text { željama. }\end{array}$ &, 023 &, 060 \\
\hline V7 Bojim se da ću ispasti glup/a pred društvom zbog svojeg mišljenja ili ponašanja. &,- 230 &,- 101 \\
\hline $\begin{array}{l}\text { V8 Odustat ću od svojeg mišljenja/vrijednosti/stavova ako se razlikuju od onih u } \\
\text { mom društvu. }\end{array}$ &,- 165 &,- 060 \\
\hline V9 Važno mi je biti popularan/na u društvu u kojem se krećem. &,- 047 &, 160 \\
\hline V10 Kad sam u svom društvu, izbjegavam osobe koje mu ne pripadaju. &, 432 &, $520^{*}$ \\
\hline V11 Moje ponašanje temelji se na ponašanju osoba iz mog društva. &, 345 \\
\hline
\end{tabular}




\begin{tabular}{|c|c|c|}
\hline Varijable & C & $\mathrm{S}$ \\
\hline V12 Kad se družim s ljudima koji uzimaju drogu, dođem u napast da je i ja probam. &,- 031 &,- 036 \\
\hline $\begin{array}{l}\text { V13 Uzimam drogu jer želim doživjeti „super“ osjećaj koji je iskusio ostatak mog } \\
\text { društva. }\end{array}$ &,- 184 &,- 046 \\
\hline V14 Važno mi je što moje društvo misli o meni. &,- 051 &,- 061 \\
\hline $\begin{array}{l}\text { V15 Kada se nađem u situaciji da svi konzumiraju alkohol, a ja ne, imam osjećaj da } \\
\text { se ne mogu uklopiti/zabaviti/opustiti. }\end{array}$ &,- 254 &,- 059 \\
\hline $\begin{array}{l}\text { V16 Važno mi je imati iste stavove, vrijednosti i mišljenje kao i moje društvo da bih } \\
\text { se dobro osjećao/la u njemu. }\end{array}$ &, 193 & , 199 \\
\hline V17 Treba mi pohvala moje „ekipe“ da bih imao/la dobro mišljenje o sebi. &,- 197 & ,006 \\
\hline V18 Mjesto izlaska biram u skladu s odabirom i ukusom mog društva. &, 147 &, 181 \\
\hline $\begin{array}{l}\text { V19 Moji prijatelji i ja teško prihvaćamo osobe koje se drukčije odijevaju ili slušaju } \\
\text { drukčiju vrstu glazbe od nas. }\end{array}$ &, 040 &, 211 \\
\hline V20 Upustit ću se u rizična ponašanja ako to moje društvo traži od mene. &, 113 & ,342 \\
\hline V21 Kladim se / kockam zato jer to rade i moji prijatelji. &, 263 & 291 \\
\hline $\begin{array}{l}\text { V22 Sudjelovao/la bih na nekom studentskom prosvjedu iako osobno ne podržavam } \\
\text { njihove ideje. }\end{array}$ &,- 175 &,- 082 \\
\hline V23 Ostajem vani dulje nego bih htio/htjela jer moji prijatelji to očekuju od mene. &, 224 &, 234 \\
\hline $\begin{array}{l}\text { V24 Osjećam se manje vrijednim/om jer imam manje seksualnog iskustva od } \\
\text { ostatka svog društva. }\end{array}$ &, 136 & ,258 \\
\hline V25 Moje društvo ima utjecaj na moje seksualno ponašanje. & ,273 & ,316 \\
\hline
\end{tabular}

*DF, Centoridi skupina: Pula - ,318; Petrinja ,361

Iz podataka prikazanih u tablici 3 proizlazi da se sudionici koji su ponekad izloženi vršnjačkom pritisku s obzirom na obilježja te podložnosti međusobno najviše razlikuju u V10 - „Kad sam u svom društvu, izbjegavam osobe koje mu ne pripadaju“ i V2 - „Ponašam se na način koji mi ne odgovara da bih se uklopio/la u grupu“, na način da studenti fakulteta u Petrinji u većoj mjeri kod sebe procjenjuju navedena obilježja. Rezultati sugeriraju da studenti u Petrinji pokazuju veću tendenciju potrebe za pripadnošću društvu. S druge strane, studenti fakulteta u Puli češće procjenjuju V3 - „Važno mi je što drugi misle o meni“. Možemo zaključiti da grad Petrinja i grad Pula ostvaruju različite stupnjeve društvenih, ali i psiholoških odnosa. U gradu Petrinji studenti se pretežito druže međusobno i to na istom fakultetu i manje im je dostupan širi krug studenta koji Pula sa svojim sveučilištem omogućuje. Iz tog razloga pretpostavlja se da je u Petrinji veća socijalna kontrola, pa tako i konformizam u ponašanju studenata kojim se žele uklopiti. S druge strane, vezano za izbjegavanje osoba koje ne pripada- 
ju skupini, može se reći da se radi o tzv. „socijalnom bojkotu“, koji je vrlo efikasno sredstvo za uspostavljanje konformizma. Kada se radi o pulskim studentima, rezultati, u skladu s tumačenjima nekih istraživanja (Susman i sur., 1994.; Prinstein, Borgers i Spirito, 2001.), pokazuju da su studenti više pod utjecajem vršnjaka i da više brinu o tome što njihovi prijatelji misle. Naime, većina preuzimanja rizika za određena asocijalna ponašanja događa se u skupinama vršnjaka, a ne samostalno, sugerirajući da vršnjaci i prijatelji imaju velik utjecaj na odluke adolescenata. Osim toga, u toj se dobi događa mnogo promjena u najširem smislu, koje mogu utjecati na odluke i ponašanje adolescenata (Steinberg, 2010.), što uključuje sposobnosti i vještine, kao i okolinu iz koje dolaze te demografske elemente. Također, kompetentni donositelji odluka koriste logičke strategije, kao što su prikupljanje informacija o situacijama, da bi donijeli važne odluke. Naime, neke studije (Byrnes, Miller i Reynolds, 1999.) ukazuju na to da studenti i odrasle osobe donose bolje odluke nakon što većeg primanja povratnih informacija, čime postaju odgovorniji za donošenje odluka i svoje ponašanje. Nadalje, razlike u samoprocjeni studenata fakulteta u Puli i Petrinji govore u prilog činjenici da okolina i javni prostori ne omogućuju mladima u jednakoj mjeri da se susreću na prividno neutralnom tlu planiranim i neplaniranim načinima, da međusobno komuniciraju s drugima u skupini u kojoj se kreću u kontekstu zajednice i okoline koja ih okružuje. To izvan obiteljskih odnosa uključuje kulturne skupine mladih, lokalne društvene veze (slučajni ili planirani sastanci s prijateljima, susjedima i radnim kolegama) i sastanke skupina kroz zajednički interes.

Radi uvida u postojanje eventualnih razlika između skupina na manifestnim varijablama, u tablici 4 navedeni su podaci o aritmetičkim sredinama, standardnim devijacijama skupina, F-testu i značajnosti (p). Usporedbom apsolutnih veličina razlika i pripadajućih standardnih devijacija uočava se da su razlike između skupina male. Pojedine manifestne varijable, (V2) „Ponašam se na način koji mi ne odgovara da bih se uklopio/la u grupu“, (V3) „Važno mi je što drugi misle o meni“, (V10) „Kad sam u svom društvu. izbjegavam osobe koje mu ne pripadaju“, (V11) „Moje ponašanje temelji se na ponašanju osoba iz mog društva“, (V20) „Upustit ću se u rizična ponašanja ako to moje društvo traži od mene“, (V21) „Kladim se / kockam zato jer to rade i moji prijatelji“ i (V25) „Moje društvo ima utjecaj na moje seksualno ponašanje“, statistički su značajne na odgovarajućim razinama značajnosti. Zaključuje se da je manjem broju studenata koji je ponekad podložan vršnjačkom pritisku, s gotovo neznatnim razlikama s obzirom na promatrane skupine studenta, važno u tom smislu pripadanje društvu u kojem se kreću, da vjeruju u svoje društvo i osobe u njemu te je vjerojatno da će stvarna ponašanja osoba iz društva utjecati i na percepciju pojedinca o razumijevanju složenih problema kao što je donošenje odluka i rizično ponašanje. 
Tablica 4.

Rezultati univarijatne analize varijance

\begin{tabular}{|c|c|c|c|c|c|c|}
\hline & \multicolumn{2}{|c|}{$\begin{array}{l}\text { Aritmetička } \\
\text { sredina }\end{array}$} & \multicolumn{2}{|c|}{$\begin{array}{l}\text { Standardna } \\
\text { devijacija }\end{array}$} & \multirow[t]{2}{*}{$F$} & \multirow[t]{2}{*}{$p$} \\
\hline & Pula & Petrinja & Pula & Petrinja & & \\
\hline $\begin{array}{l}\text { V1 Važno mi je biti sličan društvu u kojem se krećem } \\
\text { da bih se dobro osjećao/la. }\end{array}$ & 2,7 & 2,7 & 1,02 & 1,03 & 0,284 & 0,594 \\
\hline $\begin{array}{l}\text { V2 Ponašam se na način koji mi ne odgovara da bih } \\
\text { se uklopio/la u grupu. }\end{array}$ & 1,4 & 1,6 & 0,62 & 0,75 & 4,693 & $0,031^{* *}$ \\
\hline V3 Važno mi je što drugi misle o meni. & 2,9 & 2,7 & 0,82 & 0,81 & 4,868 & $0,028^{* *}$ \\
\hline V4 Svoj izgled uspoređujem s drugima. & 2,3 & 2,4 & 0,93 & 0,94 & 0,545 & 0,461 \\
\hline $\begin{array}{l}\text { V5 Moje razmišljanje i stavovi temelje se na } \\
\text { razmišljanju i stavovima mog društva. }\end{array}$ & 1,9 & 1,9 & 0,85 & 0,83 & 0,140 & 0,708 \\
\hline $\begin{array}{l}\text { V6 Važnije mi je raditi ono što vršnjaci očekuju od } \\
\text { mene nego udovoljiti vlastitim željama. }\end{array}$ & 1,4 & 1,4 & 0,64 & 0,62 & 0,180 & 0,671 \\
\hline $\begin{array}{l}\text { V7 Bojim se da ću ispasti glup/a pred društvom zbog } \\
\text { svojeg mišljenja ili ponašanja. }\end{array}$ & 1,8 & 1,8 & 0,91 & 0,87 & 0,517 & 0,472 \\
\hline $\begin{array}{l}\text { V8 Odustat ću od svojeg mišljenja/vrijednosti/ } \\
\text { stavova ako se razlikuju od onih u mom društvu. }\end{array}$ & 1,5 & 1,4 & 0,64 & 0,61 & 0,183 & 0,669 \\
\hline $\begin{array}{l}\text { V9 Važno mi je biti popularan/na u društvu u kojem } \\
\text { se krećem. }\end{array}$ & 1,6 & 1,7 & 0,83 & 0,94 & 1,300 & 0,255 \\
\hline $\begin{array}{l}\text { V10 Kad sam u svom društvu. izbjegavam osobe koje } \\
\text { mu ne pripadaju. }\end{array}$ & 1,6 & 1,9 & 0,88 & 1,05 & 13,688 & $0,000^{*}$ \\
\hline $\begin{array}{l}\text { V11 Moje ponašanje temelji se na ponašanju osoba iz } \\
\text { mog društva. }\end{array}$ & 1,7 & 1,9 & 0,81 & 0,90 & 6,024 & $0,015^{* *}$ \\
\hline $\begin{array}{l}\text { V12 Kad se družim s ljudima koji uzimaju drogu, } \\
\text { dođem u napast da je i ja probam. }\end{array}$ & 1,2 & 1,2 & 0,62 & 0,623 & 0,065 & 0,799 \\
\hline $\begin{array}{l}\text { V13 Uzimam drogu jer želim doživjeti "super“ osjećaj } \\
\text { koji je iskusio ostatak mog društva. }\end{array}$ & 1,1 & 1,1 & 0,53 & 0,50 & 0,105 & 0,746 \\
\hline V14 Važno mi je što moje društvo misli o meni. & 3,1 & 3,1 & 1,06 & 1,03 & 0,188 & 0,665 \\
\hline $\begin{array}{l}\text { V15 Kada se nađem u situaciji da svi konzumiraju } \\
\text { alkohol, a ja ne, imam osjećaj da se ne mogu uklopiti/ } \\
\text { zabaviti/opustiti. }\end{array}$ & 1,7 & 1,7 & 0,91 & 0,99 & 0,175 & 0,676 \\
\hline $\begin{array}{l}\text { V16 Važno mi je imati iste stavove, vrijednosti i } \\
\text { mišljenje kao i moje društvo da bih se dobro osjećao/ } \\
\text { la u njemu. }\end{array}$ & 1,9 & 2,0 & 0,87 & 0,93 & 2,002 & 0,158 \\
\hline
\end{tabular}




\begin{tabular}{|c|c|c|c|c|c|c|}
\hline & \multicolumn{2}{|c|}{$\begin{array}{l}\text { Aritmetička } \\
\text { sredina }\end{array}$} & \multicolumn{2}{|c|}{$\begin{array}{l}\text { Standardna } \\
\text { devijacija }\end{array}$} & \multirow[t]{2}{*}{$F$} & \multirow[t]{2}{*}{$p$} \\
\hline & Pula & Petrinja & Pula & Petrinja & & \\
\hline $\begin{array}{l}\text { V17 Treba mi pohvala moje "ekipe“ da bih imao/la } \\
\text { dobro mišljenje o sebi. }\end{array}$ & 1,9 & 1,9 & 0,93 & 0,87 & 0,002 & 0,965 \\
\hline $\begin{array}{l}\text { V18 Mjesto izlaska biram u skladu s odabirom i } \\
\text { ukusom mog društva. }\end{array}$ & 2,9 & 3,0 & 1,10 & 1,14 & 1,665 & 0,198 \\
\hline $\begin{array}{l}\text { V19 Moji prijatelji i ja teško prihvaćamo osobe koje } \\
\text { se drukčije odijevaju ili slušaju drukčiju vrstu glazbe } \\
\text { od nas. }\end{array}$ & 1,6 & 1,7 & 0,91 & 1,02 & 2,256 & 0,134 \\
\hline $\begin{array}{l}\text { V20 Upustit ću se u rizična ponašanja ako to moje } \\
\text { društvo traži od mene. }\end{array}$ & 1,2 & 1,3 & 0,49 & 0,73 & 5,918 & $0,015^{* *}$ \\
\hline $\begin{array}{l}\text { V21 Kladim se / kockam zato jer to rade i moji } \\
\text { prijatelji. }\end{array}$ & 1,0 & 1,1 & 0,13 & 0,35 & 4,284 & $0,039^{* *}$ \\
\hline $\begin{array}{l}\text { V22 Sudjelovao/la bih na nekom studentskom } \\
\text { prosvjedu iako osobno ne podržavam njihove ideje. }\end{array}$ & 1,3 & 1,2 & 0,61 & 0,51 & 0,339 & 0,561 \\
\hline $\begin{array}{l}\text { V23 Ostajem vani dulje nego bih htio/htjela jer moji } \\
\text { prijatelji to očekuju od mene. }\end{array}$ & 1,5 & 1,7 & 0,72 & 0,86 & 2,776 & 0,096 \\
\hline $\begin{array}{l}\text { V24 Osjećam se manje vrijednim/om jer imam manje } \\
\text { seksualnog iskustva od ostatka svog društva. }\end{array}$ & 1,1 & 1,2 & 0,44 & 0,56 & 3,373 & 0,067 \\
\hline $\begin{array}{l}\text { V25 Moje društvo ima utjecaj na moje seksualno } \\
\text { ponašanje. }\end{array}$ & 1,1 & 1,2 & 0,27 & 0,61 & 5,039 & $0,025^{* *}$ \\
\hline
\end{tabular}

${ }^{*} \mathrm{p}<, 01 ;{ }^{* *} \mathrm{p}<, 05$

\section{Zaključak}

U skladu s ciljevima ovoga rada, kojima se nastojalo utvrditi jesu li i u kojem obimu studenti podložni vršnjačkom pritisku i, ukoliko jesu, koja su to specifična obilježja razlika u podložnosti tom pritisku između studenata Fakulteta za odgojne i obrazovne znanosti Sveučilišta Jurja Dobrile u Puli i Učiteljskog fakulteta Sveučilišta u Zagrebu, Odsjeka u Petrinji, rezultati generalno pokazuju da su studenti obaju promatranih fakulteta procjenjivali vrlo malu podložnost vršnjačkom pritisku. $S$ obzirom na to da je udio studenata koji su ostali studirati u svom mjestu prebivališta mali, zaključuje se da obilježja okruženja nisu u većoj mjeri djelovala na podložnost vršnjačkom pritisku studenata koji su u navedene gradove došli studirati u dobi već kasne adolescencije, koju obilježava manja podložnost vršnjačkom pritisku.

S druge strane, kod studenata promatranih fakulteta koji su ponekad bili podložni vršnjačkom pritisku postoje razlike u specifičnim obilježjima te podložnosti, no one 
su također male. Temeljem dobivenih razlika zaključuje se da je kod studenata grada Petrinje veća socijalna kontrola, pa tako i konformizam u ponašaju studenata u svrhu uklapanja. Također, kod istih studenata, vezano za izbjegavanje osoba koje ne pripadaju skupini, zaključuje se da se radi o svojevrsnom „socijalnom bojkotu“, koji je vrlo efikasan način i sredstvo za uspostavljanje ranije spomenutog konformizma, koji je karakterističniji za zatvorenije sredine. Općenito se može zaključiti da izvor dobivenih razlika između studenata različitih gradova leži u različitim stupnjevima društvenih, ali i psiholoških odnosa, pa stoga studenti i različito reagiraju na vršnjački pritisak. Ujedno, društvo je okarakterizirano određenom privatnošću ili izdvojenošću uz određeni stupanj sigurnosti i povezanosti s gradom u kojem studenti žive i/ili djeluju, što posebno vrijedi za studente fakulteta u Petrinji. Neki pojedinci odražavaju vidljivu prisutnost u određenim gradskim središtima jer se često vide i susreću na istom mjestu u redovitom vremenskom razdoblju. Bez obzira na to je li njihova prisutnost dobrodošla ili ne za daljnji razvoj stavova i vrijednosti u toj skupini mladih, s obzirom na ponašanja i stavove koje iskazuju, ti mladi postaju dio te sredine (Holland i sur., 2007.). Također, pretpostavlja se da se kod manjeg broja promatranih adolescenata koji jesu podložni vršnjačkom pritisku radi i o smanjenom samopouzdanju i osjećaju manje vrijednosti, što ovom prilikom nije analizirano. Naposljetku se zaključuje da s obzirom na to da se promatrani studenti nalaze već u kasnijoj adolescenciji, manje su podložni vršnjačkom pritisku, na što utječu individualni, kontekstualni i okolinski čimbenici u životu studenata, posebice oni koji su povezani s razvojem autonomije.

Ograničenja ovog istraživanja odnose se na obim i jačinu utjecaja pojedinih obilježja promatranih gradova na razlike u vršnjačkom pritisku. Naime, različiti izdvojeni čimbenici (društveni, kulturni, gospodarski, povijesni, psihološki...) mogu, ali i ne moraju u velikoj mjeri utjecati na pojedinca i ovom prilikom nije ispitivan njihov pojedinačni utjecaj ni međusobna povezanost. Također, radi se o prigodnom uzorku sudionika (u istraživanju su sudjelovali samo oni studenti koji su prilikom ispitivanja prisustvovali nastavi), koji vrlo velikim djelom čini ženska populacija sudionika.

Znanstveni doprinos rada očituje se u uvidu o obimu vršnjačkog pritiska kod studenata, ali i sagledavanju razlika u specifičnim obilježjima podložnosti vršnjačkom pritisku studenata koji su mu podložni s dvaju srodnih fakulteta, a s obzirom na područja dvaju različitih hrvatskih gradova i županija u kojima se oni nalaze. Iako postoje mnogobrojna istraživanja koja se bave razlikama između urbanih i ruralnih sredina i njihovim obilježjima te sredinama koje su izrastale iz različitih društvenih, kulturnih, gospodarskih i povijesnih konteksta, kao i koja se bave vršnjačkim pritiskom, ne postoje ili su izrazito rijetka istraživanja o povezanosti vršnjačkog pritiska s upravo takvim, različitim okruženjima, što je dodatni doprinos ovog rada. Stoga se dobiveni rezultati mogu razmatrati u smislu teorijskih i praktičnih implikacija te mogu biti poticaj za daljnja istraživanja. 


\section{Literatura}

1. Alić, S. (2009). Globalno selo. Filozofska istraživanja, 29 (1): 51-61.

2. Allen, J. P.; Chango, J.; Szwedo, D.; Schad, M.; Marston, E. (2012). Predictors of susceptibility to peer influence regarding substance use in adolescence. Child Development, 83 (1): 337-350.

3. Bauman, K. E. and Ennett, S. E. (1996). On the importance of peer influence for adolescent drug use: Commonly neglected considerations. Addiction, 91 (2): 185-198.

4. Brown, B. (2004). Adolescents' relationships with peers, in: Lerner, R and Steinberg, L. (Eds.). Handbook of adolescent psychology. 2nd ed. New York: Wiley, 363-394.

5. Byrnes, J. P.; Miller, D. C. and Reynolds, M. (1999). Learning to make good decisions: A self-regulation perspective. Child Development, 70 (5): 1121-1140.

6. Byrnes, J. P. (2002). The development of decision-making. Journal of Adolescent Health, 31: 208-215.

7. Carlson, A. (2012). How Parents Influence Deviant Behaviour among Adolescent: An Analysis of their Family, Life, their Community and their Peers. Perspectives, 4 (1): 42-51.

8. Chassin, L.; Hussong, A.; Barrera, M., Jr.; Molina, B.; Trim, R.; Ritter J. (2004). Adolescent substance use, in: Lerner, R. and Steinberg, L. (Eds.). Handbook of adolescent psychology. 2nd ed. New York: Wiley, 665-696.

9. Dishion, T. J. (2000). Cross-setting consistency nearly adolescent psychopathology: Deviant friendships and problem behaviour squeale. Journal of Personality, 68 (6): 1109-1126.

10. Dishion, T. J.; Bullock, B. M. and Granic, I. (2002). Pragmatismin modelling peer influence: Dynamics, outcomes, and change processes. Development and Psychopathology, 14 (4): 969-981.

11. Đuranović, M. (2014). Rizično socijalno ponašanje adolescenata u kontekstu vršnjaka. Školski vjesnik, 63 (1-2): 119-132.

12. Henslin, J. (2008). Social Problems: A Down into Earth Approach. 8th ed. Boston: Allen and Bacon.

13. Holland, C.; Clark, A.; Katz, J.; Peace, S. (2007). Social interactions in urban public places. Plymouth: Latimer Trend.

14. Kaplan, P. (2004). Adolescence. Boston: Houghton Mifflin Company.

15. Kiran-Esen, B. (2003). Examining the adolescents' smoking according to their peer pressure levels and gender. Educational Sciences: Theory \& Practice, 3 (1): 179-188.

16. Knecht, A.; Snijders, T.A.B.; Baerveldt, C.; Steglich., E.G.C.; Raub, W. (2010). Friendship and Delinquency: Selection and Influence Processes in Early Adolescence. Social Development, 19 (3): 494-514.

17. Lashbrook, J. T. (2000). Fittingin: Exploring the emotional dimension of adolescent peerpressure. Adolescence, 35 (140): 747-757. 
18. Lebedina-Manzoni, M.; Lotar, M. i Ricijaš, N. (2008). Podložnost vršnjačkom pritisku i samopoštovanje kod studenata. Hrvatska revija za rehabilitacijska istraživanja, 44 (1): 77-92.

19. Lebedina-Manzoni, M. i Ricijaš, N. (2013). Obilježja mladih s obzirom na podložnost vršnjačkom pritisku. Kriminologija i socijalna integracija, 21 (1): $1-165$.

20. LeBlanc, M. and Morizot, J. (2000). Lerôledes pairsdans l'émergence et le développement de laconduite délinquante: une recension critique desécrits. [The Role of Peers in the Emergence and Development of Delinquent Behavior: A Critical Review of the Literature]. Revue Canadienne de Psycho-Education, 29 (1): 87-117.

21. Lee, R. M.; Keough, K. and Sexton, J. D. (2002). Social connectedness, social appraisal and perceived stress in college women and men. Journal of Counseling and Development, 80 (3): 355-361.

22. Lerner, R. M. and Steinberg, L. (2004). The scientific study of adolescent development: Past, present, and future, in: Lerner, R. M. and Steinberg, L. (Eds.). Handbook of adolescent psychology. Hoboken, NJ, US: John Wiley \& Sons Inc, $1-12$.

23. Lokalni program za mlade Grada Pule 2018.-2020. (2017). https://www.pula. hr/site media/media/uploads/posts/attachments/Lokalni program za mlade Grada_Pule.pdf. (Pregledano 2. svibnja 2020.)

24. Maleš, D. (1995). Između djetinjstva i zrelosti. Đakovo: Tempo shop.

25. McIntosh, J.; MacDonald, F. and McKeganey, N. (2003). The Initial Use of Drugs in a Sample of Pre-teenage School children: the role of choice, pressure and influence. Drugs: education, prevention and policy, 10 (2): 147-158.

26. Miner, M. H. and Munns, R. (2005). Isolation and Normlessness: Attitudinal Comparisons of Adolescent Sex Offenders, Juvenile Offenders, and Nondelinquents. International Journal of Offender Therapy and Comparative Criminology, 49 (5): 491-504.

27. Monahan, K. C.; Steinberg, L.; Cauffman, E.; Mulvey, E. P. (2009). Trajectories of antisocial behavior and psychosocial maturity from adolescence to young adulthood. Developmental Psychology, 45 (6): 1654-1668.

28. Nsofor, J. U. (2013). Causes and Effects of Campus Cults on Nigerian Educational System. Journal of the Nigerian Sociological Society, 2 (1-2): 139-142.

29. Prinstein, M. J.; Boergers, J. and Spirito, A. (2001). Adolescents' and their friends' health-risk behavior: Factors that alter or add to peer influence. Journal of Pediatric Psychology, 26 (5): 287-298.

30. Prinstein, M. J. (2007). Moderators of peer contagion: A longitudinal examination of depression socialization between adolescents and their best friends. Journal of Clinical Child and Adolescent Psychology, 36 (2): 159-170.

31. Program ukupnog razvoja 2014.-2020. - Grad Petrinja. https://www.petrinja. hr/dokumenti/program-ukupnog-razvoja-2014-2020, pdf. (Pregledano 17. srpnja 2019.) 
32. Raffaelli, M., and Crockett, L. (2003). Sexual Risk Taking in Adolescence: The Role of Self-Regulation and Attraction to Risk. Developmental Psychology, 39 (6): 1036-1046.

33. Sim, T. N. and Koh, S. F. (2003). A Domain Conceptualization of Adolescent Susceptibility to Peer Pressure. Journal of Research on Adolescence, 13 (1): 57-80.

34. Simons-Morton, B.; Lerner, N. and Singer, J. (2005). The observe defects of teenage passengers on the risky driving behaviour of teen age drivers. Accident Analysis and Prevention, 37 (6): 973-982.

35. Steinberg, L. (2007). Risk taking in adolescence. Current Directions in Psychological Science, 16 (2): 54-59.

36. Steinberg, L. and Monahan, K. C. (2007). Age differences in resistance to peer influence. Developmental Psychology, 43 (6): 1531-1543.

37. Steinberg, L. (2010). A behavioral scientist looks at the science of adolescent brain development. Brain and Cognition, 72 (1): 160-164.

38. Strategija razvoja Grada Pule, 2010. www.pula.hr/site.../STRATEGIJA RAZVOJA GRADA PULE 1901 2011.pdf. (Pregledano 17. srpnja 2019.)

39. Susman, S.; Dent, C.; McAdams, L.; Stacy, A.; Burton, D.; Flay B. (1994). Group self- identification and adolescent cigarette smoking: A1-year prospective study. Journal of Abnormal Psychology, 103 (3): 576-580.

40. Taylor, S. E.; Peplau, L. A. and Sears, D. O. (2000). Social psychology. New Jersey: Prentice Hall.

41. Widman, L.; Choukas-Bradley, S.; Helms, S. W.; Prinstein, M. J. (2016). Adolescent Susceptibility to Peer Influence in Sexual Situations. Journal of Adolescent Health, 58 (3): 323-329.

42. Wolff, J. M. (2012). Adolescent Decision Making and Risk Behavior: A Neurobiological Approach. (Theses, Dissertations, and Student Research). University of Nebraska-Lincoln: Department of Psycholog y. 41. http://digitalcommons. unl. edu/psychdiss/41. (Pregledano 18. srpnja 2019.)

43. Zimring, F. (1998). American Youth Violence Studies in Crime and Public Policy. New York: Oxford: Oxford University Press.

44. Zloković, J. i Vrcelj, S. (2010). Rizična ponašanja djece i mladih. Odgojne znanosti, 12 (1): 197-213.

45. Živčić-Bećirević, I.; Smojver-Ažić, S.; Kukić, M.; Jasprica, S. (2007). Akademska, socijalna i emocionalna prilagodba na studij s obzirom na spol, godinu studija i promjenu mjesta boravka. Psihologijske teme, 16 (1): 121-140. 


\title{
Distinctions in Susceptibility to Peer Pressure of Students in Different Places of Studies
}

\author{
Mirjana Radetić-Paić \\ University of Pula, Faculty of Educational Sciences Juraj Dobrila, Croatia \\ e-mail: mradeticpaic@hotmail.com \\ Jasna Kudek Mirošević \\ University of Zagreb, Faculty of Teacher Education, Croatia \\ e-mail: jasna.kudek@ufzg.hr \\ Sandra Kadum \\ University of Pula, Faculty of Educational Sciences Juraj Dobrila, Croatia \\ e-mail: skadum@unipu.hr
}

\begin{abstract}
Peer relationships play a key role in adolescence. Either indirectly or directly, these relationships result in the need to act conforming with the peers' demands, as can be noticed from the decisions that the adolescents make and how they behave. On this basis, the aim of this research is to determine whether and to what extent students are subject to peer pressure and if so, what are the specific characteristics of the differences in susceptibility to that pressure between the students studying at the Faculty of Educational Sciences of the Juraj Dobrila University of Pula, Croatia and those at the Faculty of Teacher Education of the University of Zagreb, Petrinja Department, Croatia $(\mathrm{N}=440)$. The results show that students assessed very little susceptibility to peer pressure. It is concluded that the characteristics of the setting did not significantly affect the susceptibility to peer pressure of students who came to these cities to study at the age of late adolescence, which is characterized by less susceptibility to peer pressure. Among students of the observed faculties who were sometimes subject to peer pressure, there are differences in the specific characteristics of this susceptibility, but they are also small. Based on the obtained differences, it is concluded that the students of the city of Petrinja have greater social control, and thus conformism, which students adopt to fit in. The paper contributes to the insight into the extent of peer pressure in students, and also to the perspective on differences in specific characteristics of susceptibility to peer pressure of students from two related faculties, who are subject to it. Additionally, the fact that there are no studies of this kind on the relationship of peer pressure within different settings, or are extremely rare, makes an additional contribution of this paper.
\end{abstract}

Key words: adolescents, setting, resilience, effects, peers. 